\title{
On a Fungus Allied to the Saprolegniaceæ found in the Pea-crab Pinnotheres.
}

\author{
By \\ D. Atkins, B.Sc.
}

With 13 Figures in the Text.

\section{INTRODUCTION.}

In the course of work on Pinnotheres, a fungus, which from its general characters would appear to be allied to the Saprolegniaceæ, was noticed in pea-crabs taken from mussels (Mytilus edulis) coming from beds in the estuary of the Camel near St. Issey Cliff (Padstow), from the estuary of the Yealm, and from near the junction of the Tamar and Tavy (Weir Point). Although the pea-crab lives in estuarine situations where the water is brackish, yet it may be taken in bivalves dredged in rather deep water on the coast $(\mathbf{1}$, p. 123$)$; those in the Laboratory were kept in the sea-water in ordinary circulation in the tanks and it was under these conditions that the fungus was seen to grow and produce reproductive elements. This fungus therefore attacks a marine invertebrate and, as far as I have been able to ascertain, it is the first member of the Saprolegniaceæ which has been so described. Some members of the family which occur on living freshwater fish are Saprolegnia parasitica Coker* on salmon, trout, etc.-stated by Patterson $(13$, p. 5) to be unable to grow in sea-water-Achlya Hoferi Harz on Bohemian mirror carp (8, p. 201; 2, p. 145), A. Nowickii Raciborski on a sink carp (2, p. 147), and A. polyandra and $A$. prolifera on various fish (9, p. 108), while two which are found on freshwater plankton-crustaceans are Leptolegnia caudato de Bary on Leptodora Kindtii in Denmark (14, p. 511) and Pythiopsis cymosa de Bary on Holopedium gibberum in Lake Malmagen in Sweden (14, p. 511).

The mycelium of the Pinnotheres fungus may penetrate deeply into the body of the pea-crab, surrounding the organs, and may occasionally extend into the appendages, mouth parts, and even the eye-stalks, while it is generally found in the gills (Fig. 1). Such deep penetration of the tissue of the host would appear to be somewhat unusual among the Saprolegniaceæ, but it may also be effected by the salmon fungus where

* Coker (2, p. 58) considers that the fungus described from salmon and certain other fish as Saprolegnia ferax is distinct from that species, and he names it $S$. parasitica. 
the way is prepared by Bacillus salmonis pestis, the bacteria breaking down the tissue which the fungus is then able to invade $(13$, p. 7$)$, and by $A$. Hoferi of the Bohemian mirror carp, which is also probably preceded by bacteria ( 2, p. $145 ; 8$, p. 201). In these cases the fungus may penetrate the entire dermis with the exception of the muscles. The mycelium of $L$. caudata which attacks and kills Leptodora in large numbers, sometimes almost exterminating them from certain lakes in

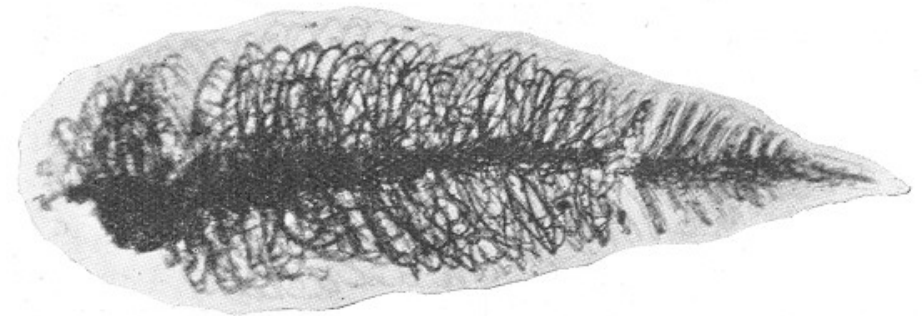

FIG. 1.-Photograph of a gill infested with the fungus, fixed in Flemming's fluid. $\times$ ca. 29 .

Denmark, is said by P. E. Müller to envelop the organs. Petersen (14, p. 512) thinks that the mycelium usually enters round the mouth opening and, spreading rapidly, kills the animal, while it finally envelops both the mother individual and the eggs with a thick meshwork of hyphæ.

\section{Description of the Fungus.}

Mussels were obtained from Padstow on the following consecutive dates, November 25/27, February 24/28, April 25/28, August 1/28, and September $14 / 28$, and a certain number of the pea-crabs taken from them on arrival at the Station either showed signs of the disease at the time or developed it later, but crabs obtained from mussels from the same place on October 11/28 were apparently free, for they did not develop it although many were kept together in bowls for about 6 weeks. Crabs which also developed the disease were obtained from near the junction of the Tamar and Tavy on March 22/28, April 10 and 20/28, and from the Yealm on July 21/28. The fungus would therefore seem to attack crabs during the greater part of the year in the comparatively mild climate of the south-west of England and is not restricted to the period of July to about the middle of September as are apparently the attacks of Leptolegnia on Leptodora in Denmark (14, p. 512). In some few instances it is certain that the crabs were already infected when taken from the mussels on arrival from the beds, and against the possibility of their acquiring the infection from the water circulating in the tanks in the Laboratory is the fact that crabs kept for over a year separately in mussels for rearing experiments have not developed the disease. 
The presence of the fungus is mostly indicated some days before the death of the crab either by opaque white patches showing through the chitin of its body and abdomen, or else more rarely by the opaqueness of the gills, though a crab may die of the disease without any outward indication. The patches in the body generally occur over the gill chamber, especially the posterior region, though as the disease progresses the whole of the roof of the gill chamber may become involved. A white line is sometimes seen along the junction of the carapace with the

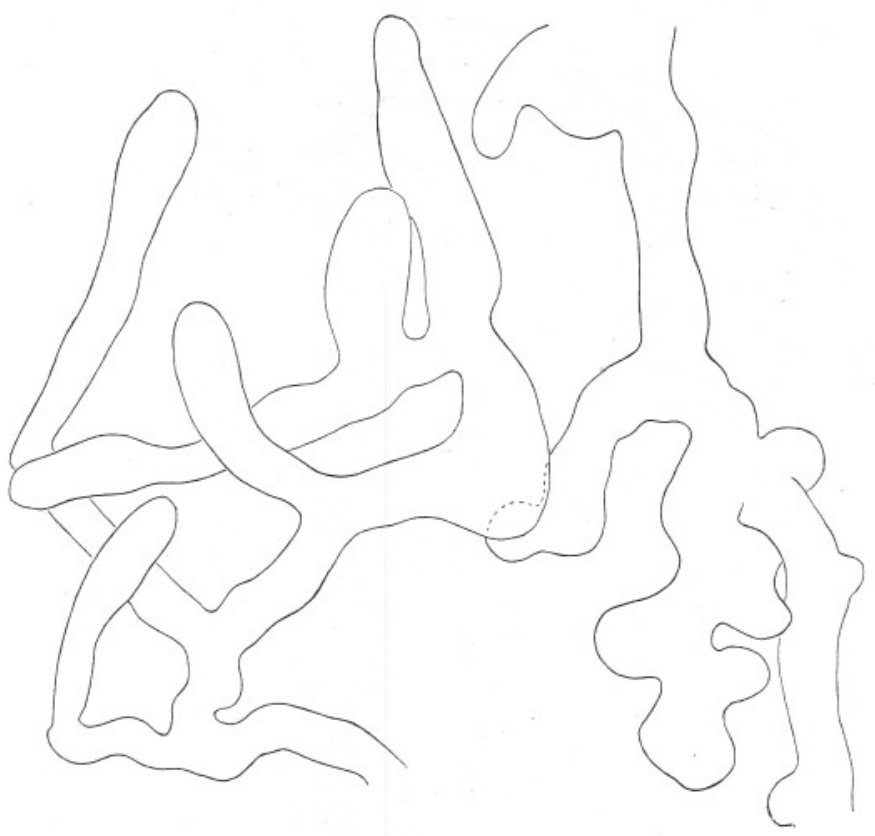

Fig. 2.-Broad, uncrowded hyphæ from roof of gill chamber. The protoplasmic contents are not shown, they were very finely granular with indication of vacuoles. $\times$ ca. 253 .

This figure and all following ones were drawn from living material.

abdomen, and patches may also occur in the abdomen, where they are generally to be found round the junction of two segments. The white appearance due to the presence of the fungus can readily be distinguished from that due to parasitisation by a Sarcosporidian identified by Dr. Pixell Goodrich; in the latter case the muscles only become an opaque white. The white patches of the fungus probably surround the original point of infection, and from their position it will be realised that the fungus enters the crab either where the chitin is extremely thin or along the fine chitinous membrane which unites the segments of the abdomen, and the posterior border of the carapace to the abdomen. The white patches are 
an intricately branched felt-like mycelium of fine hyphæ averaging about $9 \mu$ in width; occasionally very broad, uncrowded hyphæ up to about $32 \mu$ in width are found in the roof of the gill chamber (Fig. 2).

It appears that when the fungus enters through the exceedingly fine chitin roofing the gill chamber, it spreads for some distance in the tissue between it and the thicker chitin of the dorsal surface of the carapace, while it sends branches into the gills and sometimes the mouth parts. The fungus is most easily seen in these situations, but probably in some,

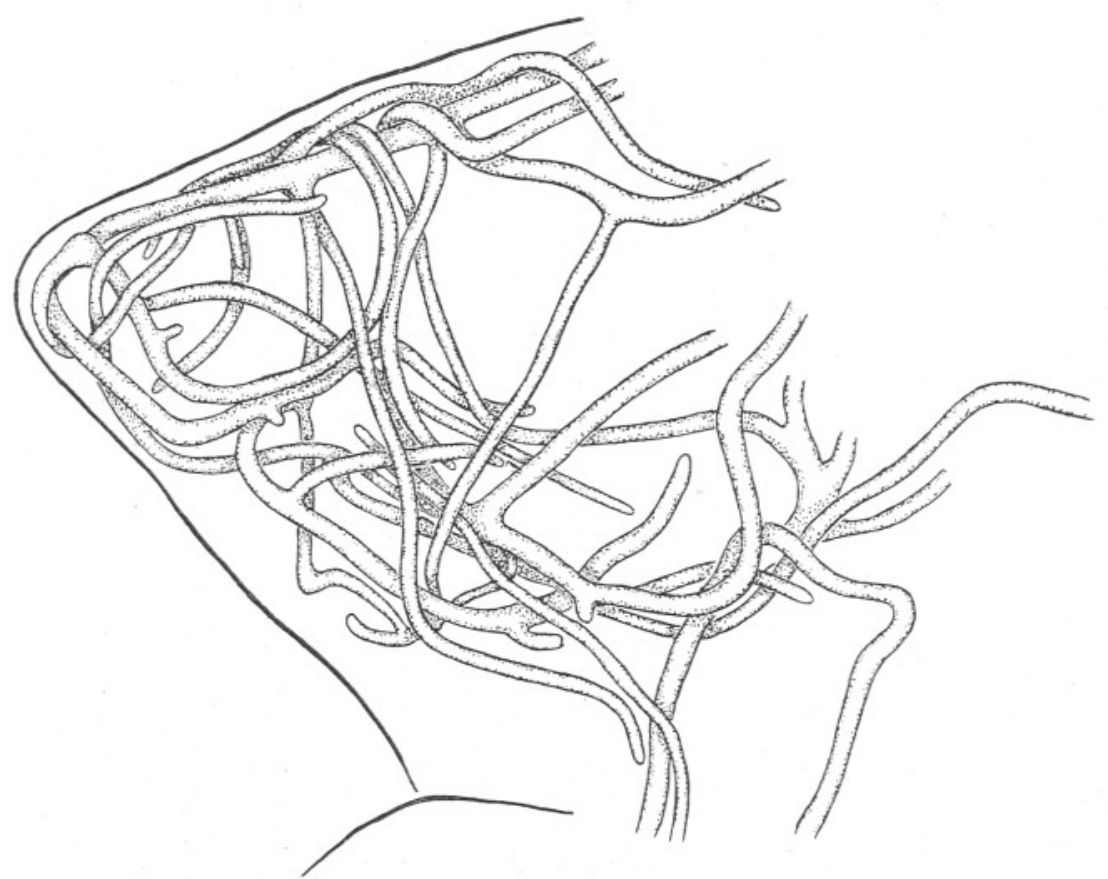

FIg. 3.-A rather heavy growth of the fungus in one of the larger leaflets near the base of a gill. $\times$ ca. 114 .

if not all cases, it also extends into the body of the crab. Perhaps the easiest way of following the hyphæ, but only possible if the crab is small and thin-shelled, is to lift off the carapace, puncture the abdomen in several places, and fix the animal in Flemming's fluid. The oil globules, often present in great numbers in the hyphæ, are blackened by the osmic acid, and the branches of the fungus can be traced after clearing the crab in glycerine. By this means the fungus was seen without dissection in the body of three small crabs.

When the fungus has once entered the gills it soon absorbs the tissue and death of the pea-crab is rapid. It is an interesting possibility that in this case death may be due to asphyxiation. 
In examining crabs for the presence of the fungus, when the white patches are absent, an inspection of the gills only has usually been relied on. A crab may die, however, when only one gill out of the six is infected, and therefore it would appear that in such a case there must be a considerable growth of the fungus in the body, unless laboratory conditions, which possibly included for these crabs shortage of food, markedly weakened them.

The fungus is most easily studied in the gills where the delicate chitinous

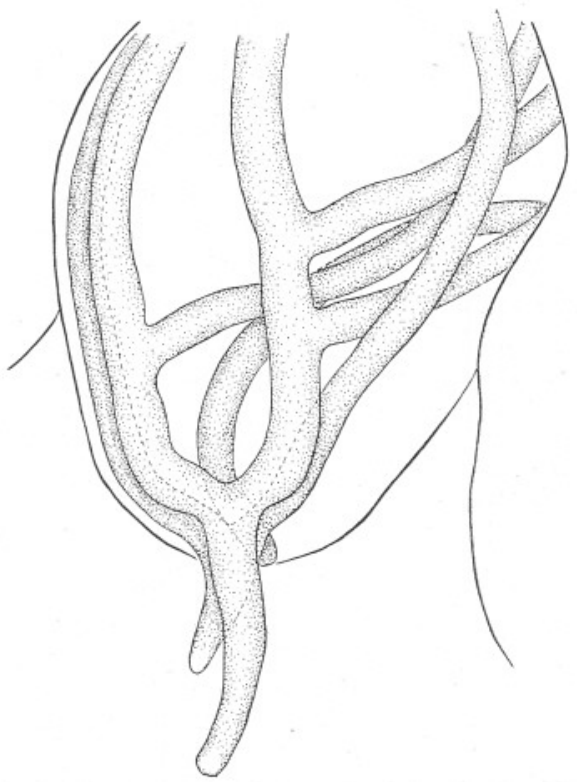

FIG. 4.-Sketch to show the very regular mode of growth of the hyphæ within the gill leaflet. The papillæ for discharging the spores are well developed but intact. The protoplasm is indicated by stippling, but no attempt has been made to show its structure. The thick lines show the outline of the gill leaflets. $\times$ ca. 253 .

covering is so thin as to be transparent (Fig. 1). The hyphæ would seem to enter through the base of the gill from the infection area in the roof of the gill chamber and pass down the axis of the gill, giving off branches into the gill leaflets, both the axis and the leaflets soon becoming crowded with richly branched hyphæ (Fig. 3). At least in the young stages of the fungus the hyphæ keep within the leaflet, passing up one edge, curving very regularly round the tip, and passing down the other edge and so into the main axis, giving off branches on the way.

The whole of the contents of the hyphæ in the gills of the host gradually 
divide into zoospores and no marked sporangia are formed. This fungus resembles Aphanomyces (2, p. 160) and Leptolegnia (14, p. 522) in that the sporangia are formed from unchanged hyphæ. Cross walls arise, but the portion cut off may be of considerable length with several branches; it may include a length running along the axis of the gill with loops into the gill leaflets, but apparently with only one exit. When the abdomen of

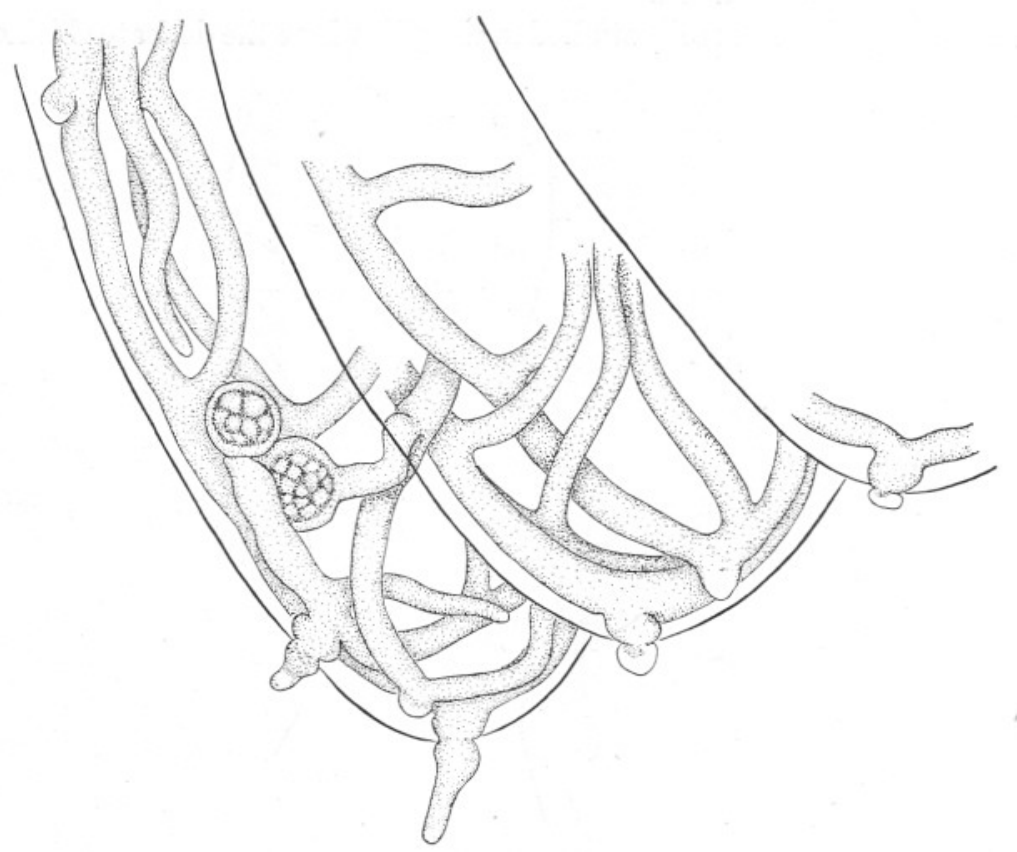

FIG. 5.- Sketch to show the fungus in three overlapping gill leaflets. Discharging papillæ are developing and show a bulge at the point of penetration of the chitin of the gill. The sketch was made at 8 p.m.; the next morning the filaments were empty, as was also the larger of the two reproductive bodies; the smaller, which had a wall dividing it from the hypha, was still full. The protoplasm is indicated by stippling, but no attempt has been made to show its structure, except in the two round reproductive bodies. The thick lines show the outline of the gill leaflets. $\times$ ca. 253 .

the crab has areas of infection, hyphæ may pass into the pleopods and there become sporangia. A characteristic of this fungus is that the sporeproducing filaments occur within the crab, though they would appear to be restricted to the gills and pleopods, the hyphæ in the roof of the gill chamber and in the body being purely vegetative. The reproductive hyphæ are generally stouter than the vegetative and are remarkably regular, tapering gradually to the tip with very clear and definite outline (Fig. 4). They vary in width from about $10 \mu$ to $20 \mu$. Gills and pleopods 
may be seen with a network of hyphæ empty except for a comparatively few spores which, unable to escape for some reason, have encysted there. The tissue of such gills and pleopods generally has disappeared entirely. It would seem that the filaments which enter these structures are entirely reproductive, though where infection takes place directly on the gill there is a tiny opaque patch of vegetative hyphæ. It may be that in the comparatively confined space of the gill or pleopod the tissue is soon consumed, and under these conditions spore formation naturally follows.

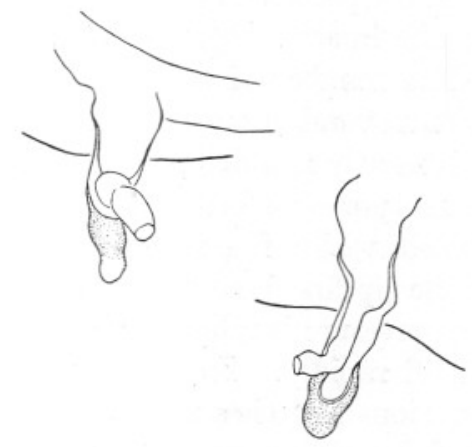

FIG. 6.-Sketches to show the development of a secondary discharging papilla when the tip of the first one has not given way. $\times$ ca. $342 \frac{1}{2}$.

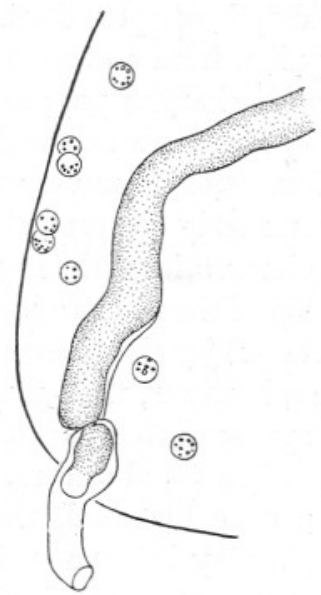

Fig. 7.-Hypha growing up within an old sporangium after the Saprolegnia type of proliferation; it is much reduced in size where it penetrates the gill chitin. The tip of the hypha is of almost clear protoplasm. A few spores are lying free on the surface of the gill leaflet, the outline of which is shown by a thick line. $\times$ ca. $342 \frac{1}{2}$.

Klebs in 1899 showed that sporangia are formed only when the food-supply is quickly and markedly decreased (15, p. 484).

When spore formation is about to take place a small branch or papilla arises either from the end of a hypha (Figs. 7, 8A) or along its length (Figs. 4, 5, 9, 12) and the tip becomes applied to and penetrates the chitin. There is a slight bulging of the tip of the papilla, before the chitin is penetrated (Fig. 5). The branches to the exterior are mostly quite short, ranging between $0.03 \mathrm{~mm}$. to $0.12 \mathrm{~mm}$. It is by these short branches or papillæ that the zoospores pass to the exterior and, with very few exceptions, this is the only part of the fungus which extends into the sea-water. In one interesting case where the long blade-like exopodite of the second 
pleopod of one side was infected, the long hairs were absent towards the tip, only their circular bases remaining, and the tips of the hyphæ were protruding through the centre of these cup-like bases. Branched discharging papillæ may occur where the tip of the original papilla has apparently failed to give way and a lateral branch has arisen through which discharge has taken place (Fig. 6).

Occasionally a new sporangium may grow up within an old one, as sometimes occurs in Leptolegnia (2, p. 157) and is typical in Saprolegnia, but the most that has been seen is one within another (Fig. 7).

The details of spore formation have not been observed. A gill which when pulled from a dead crab at night shows no sign of spore formation or of the discharging papillæ will the next morning be seen with a quantity of empty sporangia and with others in the process of discharging spores; spore formation, however, occurs in gills in situ. Spore discharge seems most commonly to occur at night. The number of spores in a row in a sporangium varies with the width, from several to one or two.

The tip of the discharging papilla is mostly rounded; it would seem to be forced off by the pressure of the zoospores packed behind it ; in one instance, however, the tip was flattened, with a fine membrane across it which appeared to dissolve. When the tip first gives way the zoospores pour out in a rapid stream, but when pressure is relieved they swim out singly; once liberated, they swim off rapidly. Zoospores within the sporangia may be seen trying the various branches until they find the exit. If the exit should be blocked by an encysted spore, or if the sporangium is very long and branched, a considerable number of spores may be retained, becoming encysted.

The time during which the first zoospores may remain active varies considerably. They are apparently very susceptible to changes in the environment, for the placing of a cover-slip over a drop containing motile spores, just out of a sporangium, causes rapid encystment. Both within the sporangium and outside, zoospores may come to rest while still irregular in shape ; this is probably due to sudden change in the environment, such as increasing salinity on the slide. On the other hand, zoospores seen coming from a sporangium at 9.30 p.m. were taken up in a fine pipette and put on a cover-slip as a hanging drop; many were still active 50 minutes later. The length of time during which the zoospores may remain active seems unusually long for the first zoospores, which in the Saprolegniaceæ apparently encyst after 5 to 15 minutes.

The first zoospores are of two sizes, large and small, as in S. anisosporc de Bary (2, p. 33) ; the small are, however, comparatively rare. The small ones are about $8 \mu$ in length, the large about $14 \mu$. Fig. $8 \mathrm{~A}$ and $\mathrm{B}$ shows sporangia from different parts of the same gill, one containing a few small zoospores, the other containing large ones; the smaller appear to be more 
regular in shape. Zoospores of intermediate size occur. The zoospores within the sporangia vary considerably in shape, especially in different sporangia. They may be oval, pear-shaped, or very elongated, almost rod-shaped, and may be rather irregular in outline, while some have a distinct protoplasmic tail. The zoospores appear capable of changing their shape to some extent, are slightly amœboid (Fig. 9). They are considerably flattened, as may be seen when they turn up an edge in swimming. It is probable that when free in the water they become a

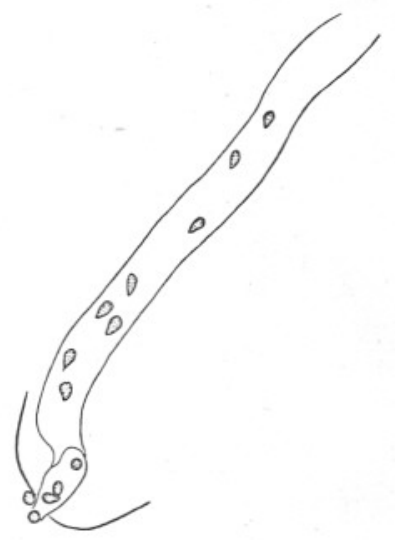

A

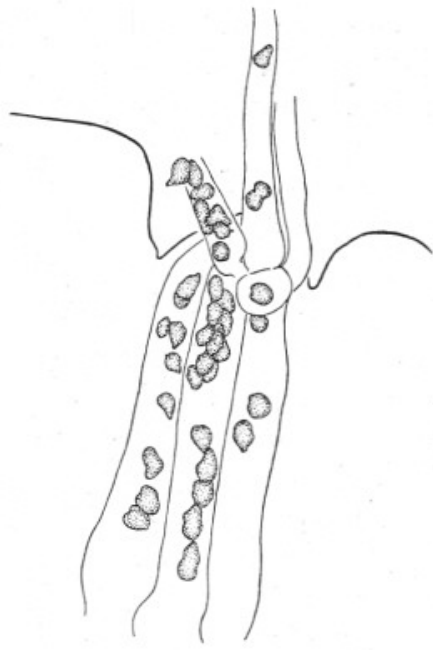

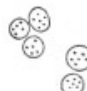

6

FIG. 8,-A. Zoosporangium with small zoospores. In the lower right-hand corner are cysts formed from some of these spores within the sporangium. B. Zoosporangium with large zoospores. In the lower right-hand corner are cysts formed from some of the spores within the sporangium. $\times$ ca. 253 .

more regular pear-shape. Zoospores swimming in the sporangia always keep the same end foremost, but in some cases the fore end is blunt, in others rather pointed, though generally all in the same sporangium swim with the same end foremost. The free zoospores have many shining droplets, and a small vacuole near the apex; they are biciliate but swim rapidly enough to make the number of the cilia and their attachment very difficult to discern. They move with the pointed end foremost and tend to swim in wide circles. The smaller zoospores, which seem to have a more regular shape, swim in a more straightforward manner and more rapidly. They often swing round in their tracks; this volteface could be more easily understood if there were an anteriorly and a 
posteriorly directed cilium. One apically attached cilium can be seen clearly, a second is sometimes glimpsed but is much more difficult to distinguish. A possible explanation is that this one, though also apically attached, is normally posteriorly directed and therefore often hidden by the body of the zoospore. In an attempt to make certain of the point of attachment of the cilia, zoospores were fixed in vapour of glacial acetic acid, then treated with iodine, but drops of sea-water containing the zoospores were also swarming with bacteria, which were particularly thick round the spores and often tended to arrange themselves on fixing, end to end in crinkled lines, sometimes touching the spores, so that any cilia were entirely hidden.

An interesting case was noted of spores emerging from a sporangium

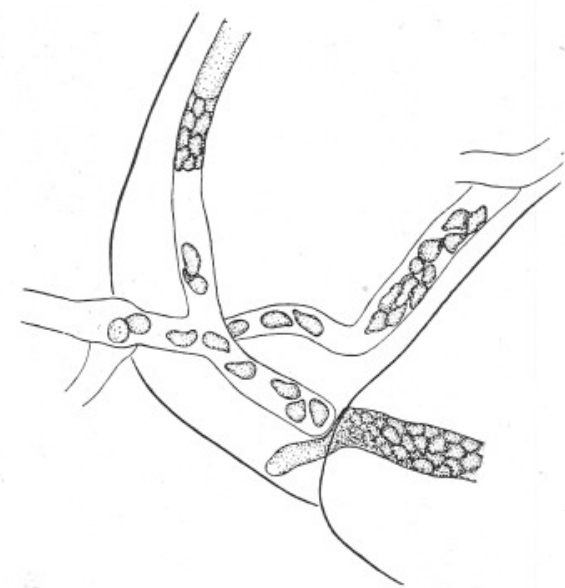

FIG. 9.-Sketch showing slightly amœboid zoospores within sporangia. A spore has encysted in the discharging papilla of one sporangium making it difficult for the zoospores to pass. $\times$ ca. $342 \frac{1}{2}$.

by way of a tiny discharging papilla which was markedly constricted where it penetrated the chitin of the gill. The emerging zoospores took a considerable time to pass through, they were almost pinched in half and detained there for perhaps 30 seconds. After passing through they halted at the exit for a few seconds as though held up by a posterior cilium or protoplasmic process adhering to the wall of the papilla; they would fling themselves sideways in an effort to become free.

As mentioned previously the length of time before encystment varies considerably, as does also the time taken actually to encyst. They may take several minutes in the process, swinging round and round in small circles and becoming more and more rounded until at last movement ceases; or a zoospore may stop abruptly when swimming rapidly, and, 
as it were, tucking in the pointed end, become rounded in a second. When rounded the spore often swings round for a short time, and at least one cilium can be seen lashing. The spore comes to rest, a shining droplet appears on the tip of the cilium as it gradually shortens, and while still of some length it breaks off and floats away. This process of events was seen very clearly perhaps a dozen times and the path of the drifting cilium followed for a second or so. Generally only one cilium has been clearly seen during this process. The shortening of the cilia with the appearing of a droplet was noted by Butler in the encysting zoospores of Pythium de Baryanum Hesse (Pythiaceæ) (6, p. 94). On one occasion a zoospore of the Pinnotheres fungus, seen when about to encyst, had two

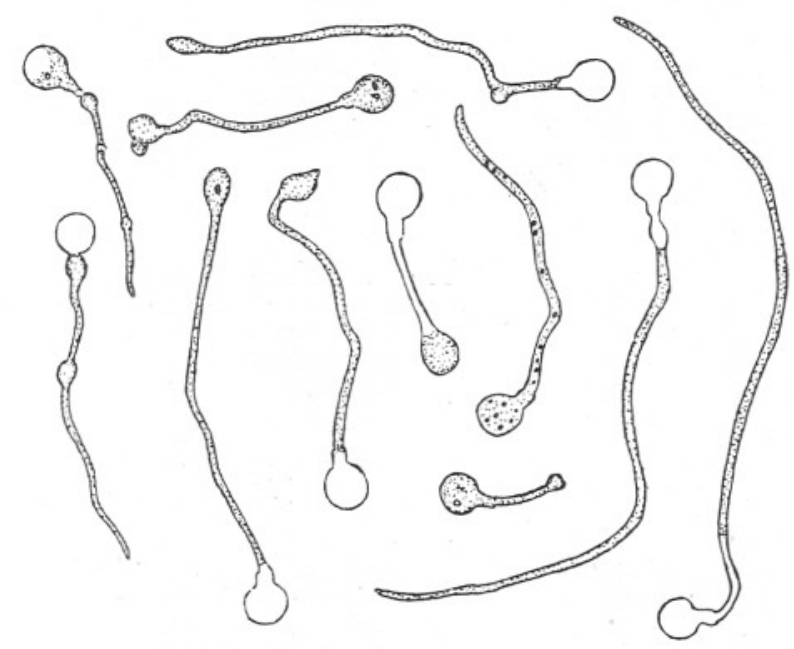

FIG. 10.-Germinating cysts. Some have small swellings along the length of the germ tube and one seems to be attempting to re-encyst. $\times$ ca. 685 .

apical cilia which curled in towards each other; then broke off and floated away. The cysts vary from about $6 \mu$ to 10 or $11 \mu$ in diameter; they contain several shining globules. A fine germ tube is put out, but since no nutritive medium was supplied, as the tubes grew in length the part next the cysts was gradually left empty and after a time the plant died. Small swollen structures occur along the germ tube (Fig. 10), some nearly as large as the original cyst, as though there was an attempt at re-encystment (3, p. 283).

The question of the structure of the zoospores and as to whether there are two motile phases has had to be left, at least for the present, in a very unsatisfactory state. Owing to lack of time no attempt was made to obtain pure cultures and, as already mentioned, it was found impossible otherwise to obtain a drop containing zoospores that was not swarming 
with bacteria, hiding the cilia. A second zoospore has not been observed emerging from a cyst, all that can be brought forward in favour of the existence of two motile phases in this fungus is, firstly, the finding of empty cyst cases with tiny exit tubes: the empty cases showed up quite clearly owing to the thick zone of bacteria collected round them. Secondly, the occurrence of a few zoospores of a definite bean-shape with two cilia which appeared to be laterally inserted, answering to the description of the second zoospores of the Saprolegniaceæ. These came from a sporangium, but may have emerged from spores encysted there.

Difficulty was experienced with growing the fungus in hanging drops of sea-water; it was found that the development of the fungus in the

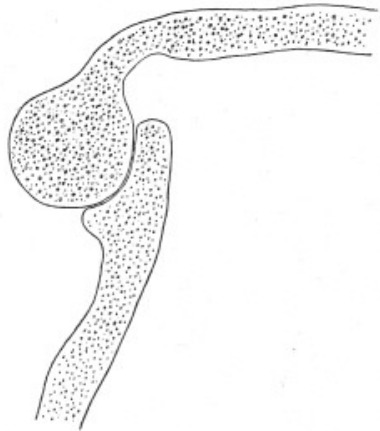

FIG. 11.-Young oogonium with applied antheridium (?). $\times 400$.

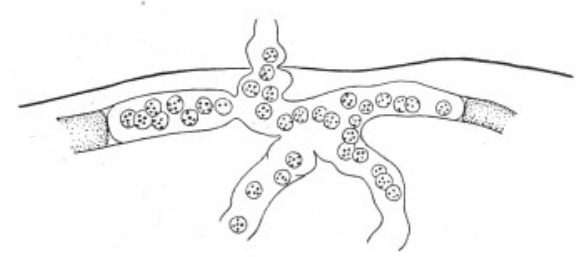

FIG. 12.- Sketch to show part of a branched sporangium with a single aperture; a number of zoospores have encysted within it. The thick line shows the outline of the gill leaflet. $\times$ ca. 253 .

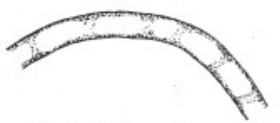

FIG. 13.-Sketch to show the highly vacuolated nature of the protoplasm in hyphie which very occasionally grow out from the gill into the seawater. $\times$ ca. $342 \frac{1}{2}$.

gills in such drops was arrested after a day or two, but that development would go forward and spores form if they were changed into a bowl of sea-water, even if growth had been at a standstill for 14 or so days. A somewhat similar state of affairs has been described by Lechmere (11, p. 318) for a species of Saprolegnia. The cysts formed in some of the hanging drops, probably owing to artificial conditions, did not develop and after a few days became enlarged, while their contents shrunk away from the wall, in some cases stretching in a band across the cell.

The infection and death was observed of a tiny nematode worm which had accidentally become fixed by its posterior extremity near the edge of a hanging drop made with an infected gill. The spores settled in the first place on the motionless tail of the worm ; the rest of the body was writhing vigorously for over 16 hours.

Sexual organs have not been definitely identified. Fig. 11 shows what 
appears to be a young oogonium about $32 \mu$ in diameter with an applied antheridium of diclinous origin. In gills fixed in Flemming's fluid a very few round bodies containing many black globules of varying size have been seen. Similar bodies are shown in Fig. 5 which was sketched from fresh material. They appeared as shown at night, the next morning the larger one and the hyphæ were empty, the smaller still full. On two or three occasions two round bodies have been seen in proximity as in this figure. There is a possibility that they may be oogonia or gemmæ, but in any case they are exceedingly rare and are formed on spore-producing hyphæ.

\section{LIFE-HISTORY (SO FAR AS KNOWN).}

The mycelium enters the pea-crab in places where the chitin is extremely thin, and round the point of infection the hyphæ form a densely woven patch. In cases where the entrance is effected through the roof of the gill chamber, some strands pass into the body while hyphæ invade the gills and mouth parts. When the tissue of the gills is partly absorbed and the death of the crab is imminent, the hyphæ in these parts turn into zoosporangia, swarms of zoospores being liberated. These remain active under laboratory conditions for a period of a few up to at least 50 minutes, when they encyst. After encystment a second motile period may occur. Infection probably occurs during one or other of the motile phases. Organs which have been recognised as possibly sexual would appear to be rare.

\section{Discussion of Relationships.}

The Pinnotheres fungus has the general characters of the Saprolegniaceæ, the hyphæ, which are freely branched and unconstricted, are aseptate until the approach of the reproductive stages, and the asexual spores are biciliate. The zoosporangia are formed from unchanged hyphæ, as in Aphanomyces (2, p. 160) and Leptolegnia (14, p. 522); they are mostly branched (Fig. 12) as Coker (2, p. 159) observed for the sporangia in old cultures of Leptolegnia which may become very complex from the extension of a single sporangium into a number of adjoining branches. In both Aphanomyces and Leptolegnia, however, the spores are typically formed in a single row, while in the Pinnotheres fungus the number varies with the width of the sporangium. Very occasionally a second sporangium is formed within an empty one, a feeble development of the "nested" arrangement found in Saprolegnia and sometimes in Leptolegnia (2, pp. 22, 157). The biciliate zoospores on emerging from the sporangia swim actively away as in Saprolegnia, Leptolegnia, and Isoachyla (2, pp. 22, 157,$81 ; 6$, p. 83), and it is possible that after encystment a second zoospore emerges as also occurs in those genera. As previously mentioned, the first 
zoospores are probably of two sizes, large and small, with intermediate sizes as in S. anisospora de Bary.

The Pinnotheres fungus is distinguished from species of Saprolegniaceæ growing on freshwater animals and apparently from all other members of the family $(6, p .82)$ by being almost entirely an internal parasite, the discharging papillæ of the sporangia only, with very rare exception, penetrating the chitin of the host and reaching the exterior. It is extremely rare for there to be any growth of the fungus, apart from the discharging papillæ, external to the host, but an exceedingly slight external growth was noticed on three occasions on gills. Such filaments are very different in appearance from the normal internal hyphæ from which they arise, they are very fine and exceedingly vacuolated, the squarish vacuoles stretching across the width of the hyphæ (Fig. 13). Similar very slender, highly vacuolated hyphæ were seen extending from a few well-developed embryos of $P$. pisum; the hyphal threads radiating from the embryos had the appearance of a halo. These were found on August 21st and 12 days later the female, which was carrying the embryos, was found dead with white opaque patches on the abdomen and with the gills infested with the usual fungus.

Dead infected crabs, left in sea-water, show no external growth of the fungus and it seems probable that it dies soon after the crab. This is in striking contrast to the heavy external growth formed by S. parasitica on dead salmon and other fish, dead flies, beetles, etc. (10, pp. 321, 331), indeed this latter species is said by Patterson $(13$, p. 1) to show a richer growth on dead than on living salmon, indicating that dead tissue is much more suitable for its growth than the living fish. The apparent inability of the Pinnotheres fungus to form a growth on dead crabs may seem to argue in favour of its truly parasitic nature, but putrefaction of Pinnotheres is somewhat rapid and it may be that the number of bacteria, etc., present, check the growth of the fungus and kill it $(14$, p. $506 ; 10$, p. 331$)$.

The question as to whether it is a true parasite or only invades tissue which has been broken down by parasitic bacteria, as does $S$. parasitica of the salmon (13, pp. 2,7 ; 4, p. $200 ;$ \%, p. 29) and perhaps A. Hoferi of the Bohemian mirror carp ( 2, p. 145$)$, has not been gone into: there is quite a possibility that this may be so, for gills infested with the fungus are almost always swarming with bacteria of several kinds. If it is a true parasite it would seem to be ill adapted to its host, for its penetration into the gills must soon cause the death of the host.

It is very probable that death occurs more rapidly under laboratory than under natural conditions. In the case of the crabs, of which details are given in Table I, they had been taken from mussels, being themselves parasites (12), and were isolated free in batches varying in number from 
TABLE I.

Mortality of Pea-crabs, Infected with the Fungus, when kept together in Bowls.

Number of crabs in a bowl, all of

which died with the infection.

5 (4 adult + + 1 o $)$ from

Weir Point, April 10/28

12 (ㅇ adult) from

Padstow, April 25/28

13 (ㅇ adult) from

Padstow, April 25/28

7 (Q adult) from

Padstow, April 25/28

3 (아 berried) from

Padstow, April 25/28

7 (ㅇ adult) from

Padstow, April 25/28

21 (ㅇ adult) from

Padstow, April 25/28

18 (ㅇ adult) from

Padstow, Sept. 14/28

Date of placing

April 10, 1928 April $28 \quad$ May 18

April 25

May 22

June 6

April 27

May 12

May 25

May 8

May 26

June 8

May 8

June 4

June 13

May 28

June 15

May 22

June 11

October 20

19

Number of days Number of days

between lst and between placing in last death. bowl and last death.

Number of days

18

20

38

27

15

42

May 10

October 6

Average 19.4 
5 to 21 in bowls of sea-water and therefore possibly able to obtain little food. When a number of crabs were kept together in a large glass dish, as in the eight instances given in Table I, they gradually died of the disease, one after the other succumbing. Mortality was very much lower among those crabs kept singly in finger bowls, indicating that the disease is extremely infectious. All crabs in the Laboratory had their water renewed every day or every other day.

The death of the host is generally sufficiently rapid, at least in the Laboratory, for the gonad - so far as appears outwardly — not to be affected. This is a condition contrary to that which occurs in infection by a Sarcosporidian identified by Dr. Pixell Goodrich, and in infection by Pinnotherion vermiforme Giard and Bonnier (5). In some few cases, mostly crabs which when taken from the mussels were seen to be infected, the crabs were rather orange or milky orange in colour. This possibly indicates that they may resist the fungus longer under natural conditions and there is time for them to draw on the gonad. In one dead crab examined, which had been a milky orange for some time, the fungal threads were found among degenerating ova in the gonad. The main axis of each of the gills was full of a bright yellowish orange substance, which looked like yolk globules, but did not blacken with the osmic acid in Flemming's fluid, and was doubtless derived from the degenerating ova.

\section{SUMMARY.}

A fungus, most probably allied to the Saprolegniaceæ, has been found infecting Pinnotheres. Pea-crabs so infected always die, but there is not as yet sufficient evidence to determine whether the fungus is pathogenic or only invades tissue which has been destroyed by parasitic bacteria. Although having the general characters of the family it apparently differs from all members so far described in that it occurs in a marine invertebrate and is almost entirely internal in habit, the zoosporangia occurring within the tissue of the host.

\section{ACKNOWLEDGMENTS.}

The work was carried out at Plymouth while holding a Miss Busk studentship of Bedford College. I wish to thank the College authorities for allowing me to work at the Marine Station, and the London University for granting me the use of their table. My thanks are also due to the Director and Staff for their kindness, and I am especially indebted to Dr. J. H. Orton for criticism and advice throughout the work. Miss G. L. Naylor most kindly read the manuscript. I am in addition indebted to several members of the Staff, and especially to Mr. A. J. Smith for the photograph in Fig. 1. 


\section{REFERENCES.}

1. Bell, T. A History of the British Stalk-eyed Crustacea. London, 1853.

2. Coker, W. C. The Saprolegniaceæ, with notes on other Water Molds. Univ. of North Carolina Press, 1923.

3. Collins, M. I. Notes on certain variations of the sporocyst in a species of Saprolegnia. Proc. Linn. Soc., New South Wales, Vol. XLV, Part 2, 1920, p. 277.

4. Drew, G. H. Some notes on parasitic and other Diseases of FishA Recurrence of the Salmon Disease in the Colne. Parasitology, Vol. II, No. 3, 1909, p. 193.

5. Giard, A., and Bonnier, J. Sur un nouvel Entoniscien (Pinnotherion vermiforme nov. gen. et nov. sp.) parasite du Pinnothère des Modioles. C.R. Acad. Sci. Paris, Tome 109, 1889, p. 914.

6. Gwynne-Vaughan, H. C. I., and Barnes, B. The Structure and Development of the Fungi. Camb. Univ. Press, 1927.

7. Hardy, A. D. Association of Alga and Fungus in Salmon Disease. Proc. Roy. Soc. Vict., n.s., Vol. XXIII, Part I, 1910, p. 27.

8. Harz, C. D. Achlya Hoferi, eine neue Saprolegniacee auf lebenden Fischen. An abstract in Journ. Roy. Micro. Soc., 1907, p. 201, from Allg. Fischerei-Zeit., Vol. 31, 1906, p. 365.

9. Hofer, B. Handbuch der Fischkrankheiten, Stuttgart, 1906.

10. Huxley, T. H. Saprolegnia in Relation to Salmon Disease. Q.J.M.S., Vol. 22, 1882, p. 311.

11. Lechmere, A. E. An Investigation of a species of Saprolegnia. New Phytologist, Vol. IX, 1910, p. 305.

12. Orton, J. H. Mode of Feeding and Sex-Phenomena in the Pea-crab (Pinnotheres pisum). Nature, Vol. 106, 1920-21, p. 533.

13. Patterson, J. H. Parliamentary Report on the Salmon Disease presented by the Fishery Board for Scotland, 1903.

14. Petersen, H. E. An Account of Danish Freshwater-Phycomycetes, with biological and systematical remarks. Ann. Myc., Vol. VIII, 1910 , p. 494.

15. Pieters, A. J. New Species of Achlya and of Saprolegnia. Bot. Gaz., Vol. LX, 1915, p. 483.

16. Ryder, J. A. On the Retardation of the development of the ova of the Shad (Alosa sapidissima) with observations on the egg fungus and bacteria. U.S. Commission of Fish and Fisheries. Part IX, Report of the Commissioner for 1881, p. 795. 
